\title{
APPLIED MATHEMATICS CONCEPTS SELF-LEARNING THROUGH THE USE OF SHORT EDUCATIONAL VIDEOS
}

\author{
Maria del Carmen Bas, Joan Albert Silvestre-Cerdà, Ramon Sala, Robert \\ Meneu, Trinidad Casasús, Rafael Benítez
}

Departament de Matemàtiques per a l'Economia i l'Empresa, Universitat de València (SPAIN)

\begin{abstract}
It is sometimes difficult for the student to participate actively in the learning process due to the difficulty that teachers find when trying to cover all the contents of a course with sufficient time and attention. This lack of time prevents professors from properly stimulating the student's active participation in class, which is always necessary for achieving a deep and significant learning. The present paper describes a flipped-classroom-based methodology that fosters autonomous learning of applied mathematics contents using short educational videos. The use of on-line media learning resources has dramatically increased in the last decade in higher education, not only under the well-known flipped classroom approach but also as replacement of conventional face-to-face lectures. The application of this methodology will give professors more time to make students work actively and cooperatively at class in the application of mathematical techniques for solving complex exercises and problems.
\end{abstract}

Keywords: teaching resources, flipped classroom, self-learning, active learning, cooperative learning, video lectures.

\section{INTRODUCTION}

In recent years, institutions of higher education have experienced various changes conditioned by the demands of today's society. The adaptation of the degree titles to the European Higher Education Area and the widespread use of Information and Communication Technologies (ICT) in the field of higher education are factors that have led to a change in the application of teaching methodologies, and to a need to adapt and make flexible the educational offer to the current reality.

The need for a change in the university education model imposed by the establishment of the European Higher Education Area has promoted the execution of numerous proposals for innovation in university teaching in order to improve qualitatively the practice of teaching and, consequently, the learning process of the students.

These new changes require teachers to redesign their subjects and to reflect on how to introduce new technologies in their subjects with the aim of improving the learning outcomes of students. One of the main tasks of the teaching staff is to foster the development of abilities to reason, to think, to deduce and to infer new knowledge, using the new teaching-learning methodologies of the digital era [1].

Sometimes it is difficult for the student to participate actively and autonomously in the learning process, mainly due to a lack of interest and motivation, causing a decrease of their academic performance [2]. With the introduction of the new degrees, students are expected to be protagonists of their own learning, being capable of preparing independently part of the contents of the subject [3] [4]. However, these purposes must be accompanied by an appropriate restructuring of the education system, to ensure they become successful.

Teachers typically face two problems in order to change the teaching system so that the student can become the protagonist of his/her own learning. On the one hand, the lack of in-class time to cover all theoretical and practical contents of the program; and, on the other hand, the potential knowledge deficiencies the students might have at the beginning of the subject, which cannot be covered by the professor. In this scenario, we consider the following questions:

- There exist measures or methodologies that can help to achieve active learning?

- How can we help the student to prepare part of the contents of the subject in an autonomous way? 
It is very important to provide students with high-quality teaching materials that could allow them to prepare the subject in an active and autonomous way. Although traditional notes, books, practice scripts, bibliography, etc. are indeed provided, the current context requires going beyond in the generation of teaching material.

In this study we describe the deployment of a flipped-classroom methodology over the "Mathematics I" subject of the Business Administration and Management degree at the Faculty of Economics of the Universitat de València, using custom generated video lectures for this purpose. This work has been developed within the research project "Aprenentatge autònom i cooperatiu, i assimilació de continguts mitjançant l'ús de vídeos docents", granted by the Universitat de València.

\section{METHODOLOGY}

The purpose of this study is to generate and introduce video lectures as complementary material in order to apply a flipped-classroom methodology in a university mathematics subject. The flippedclassroom methodology consists in converting the traditional teaching model into a model in which a set of digital learning materials are provided in advance to the student, in order to make him/her learn them right before attending each course session. In this way, classroom sessions become practical classes where the students work actively and cooperatively, and the teacher acts as a guide. These video lectures can be used later to reinforce theoretical concepts of the subject and to prepare the subject for evaluation.

Among the advantages of the flipped-classroom methodology, we can highlight a greater involvement of the student, a more significant and collaborative learning, more adaptation to each student's learning pace, an increase of classroom hours devoted to solve doubts, and a more flexible learning process thanks to the usage of ICTs. In addition, its application can contribute to the acquisition of three of the generic competences that appear in the teaching guide of the "Mathematics I" subject: the ability of team-working, the ability to use ICTs in their field of study, and the capacity of autonomous learning.

All this work has been done under the aforementioned research project "Aprenentatge autònom $i$ cooperatiu, $i$ assimilació de continguts mitjançant l'ús de vídeos docents". The specific objectives of this project are the following:

- Objective 1. Generate video lectures as support material for the subject «Mathematics I».

- Objective 2. Foster autonomous learning of students through the use these video lectures.

- Objective 3. Make students work actively and cooperatively in classroom.

- Objective 4. Evaluate the suitability of the methodology in the subject.

- Objective 5. Evaluate the quality of the video lectures generated in the project.

\section{RESULTS}

As stated before, the proposed methodology has been deployed into the "Mathematics I" subject, which covers many algorithmic processes, such as the resolution of equation systems, calculation of determinants, inverse of matrices, differentiation, integration, etc. Given that this subject is present in various degrees (Business Administration and Management; Economics, Finance and Compatibility) the impact of the project is expected to be high, as the estimated potential audience of our generated video lectures for the $2018-2019$ course is more than 1,400 students.

\subsection{Methodology development (Phases and Activities)}

The application of this methodology consists of the execution of three sequential phases that go in line with the project objectives. Figure 1 shows a dependency graph of these phases. These phases are described in detail as follows. 


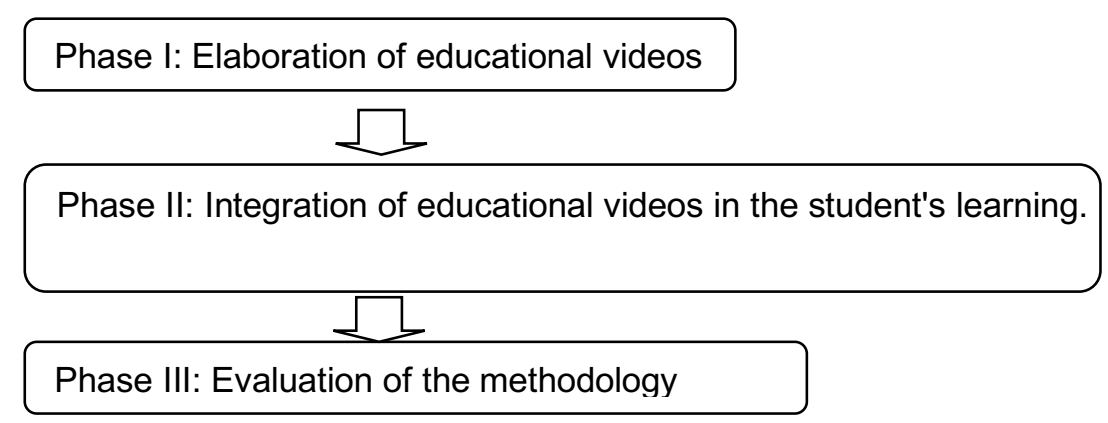

Figure 1. Methodology phases of the innovation study.

Phase I: Elaboration of educational videos.

In this phase, the Objective 1 is developed through these tasks:

- Task 1.1: Definition of a list of video lectures to be recorded.

- Task 1.2: Generation of video lectures that cover theoretical concepts of the subject.

- Task 1.3: Generation of video lectures that cover practical examples and exercises.

Table 1 lists all videos that have been created in this phase, classified by topic.

Table 1. Educational videos.

\begin{tabular}{|c|c|c|}
\hline Topics & Tittle of the video & Author \\
\hline \multirow{6}{*}{ Basic algebra concepts } & Arrays and operations with arrays & Sala, R. \\
\hline & Determinants and reverse matrix & Sala, R. \\
\hline & Solution of systems of linear equations applying Gauss & Casasús, T. \\
\hline & Solution of systems of equations applying Cramer & Sala, R. \\
\hline & Solution of equations systems with EXCEL & Sala, R. \\
\hline & Solution of systems of nonlinear equations & Casasús, T. \\
\hline \multirow{3}{*}{$\begin{array}{l}\text { Limits and continuity of } \\
\text { functions }\end{array}$} & Homogeneous function & Bas, M.C. \\
\hline & Composite function & Bas, M.C. \\
\hline & Implicit function & Bas, M.C. \\
\hline \multirow{5}{*}{ Derivability of functions } & Calculation of derivatives & Meneu, R. \\
\hline & Applications of partial derivatives in Economics & Meneu, R. \\
\hline & Successive derivatives & Sala, R. \\
\hline & Vector gradient and Jacobian matrix & Silvestre, J.A. \\
\hline & Hessian matrix & Silvestre, J.A. \\
\hline \multirow{3}{*}{$\begin{array}{l}\text { Differentiability of } \\
\text { functions }\end{array}$} & Applications of the differential in Economics & Meneu, R. \\
\hline & Differentiability of the composite function & Bas, M.C. \\
\hline & Differentiability of the implicit function & Bas, M.C. \\
\hline \multirow{6}{*}{$\begin{array}{l}\text { Introduction to integral } \\
\text { computation and } \\
\text { differential equations }\end{array}$} & Calculation of primitive integrals & Silvestre, J.A. \\
\hline & Integration by parts & Silvestre, J.A. \\
\hline & Integral of Riemann & Casasús, T. \\
\hline & Improper integrals (type I) & Benítez, R. \\
\hline & Improper integrals (type II) & Benítez, R. \\
\hline & Differential equations with separable variables & Benítez, R. \\
\hline
\end{tabular}

Video lectures were published in the virtual platform of the Universitat de València to make them accessible to all students, even to those that did not participate in the flipped-classroom methodology. 
Phase II: Integration of educational videos in the student's learning.

In this second phase, Objectives 2 and 3 are developed through these two tasks:

- Task 2.1: Foster autonomous learning via the usage of video lectures. The student learns theoretical concepts at home. The teaching staff indicates what material they must prepare for each session.

- Task 2.2: Promote active and cooperative learning in class. As the students learn theoretical concepts from the corresponding video lectures at home, these learnt concepts are tested in class through the realization of exercises and problems in a cooperative way.

It must be noted that Tasks 2.1 and 2.2 were carried out in parallel with Tasks 1.2 and 1.3 (generation of video lectures).

Phase III: Evaluation of the methodology.

This phase encompasses objectives 4 and 5 . The tasks to be carried out are the following:

- Task 3.1: Design of a satisfaction survey to assess the video lectures and the learning methodology.

- Task 3.2: Run the survey with the students who have followed the methodology.

- Task 3.3: Analyse the results of the survey.

Please note that Tasks 3.2 and 3.3 are still pending to be executed.

\section{CONCLUSIONS}

In this paper we have presented the work carried out so far under the educational research project "Aprenentatge autònom i cooperatiu, i assimilació de continguts mitjançant I'ús de vídeos docents". In this project we introduced the flipped-classroom methodology to the "Mathematics I" subject of the Faculty of Economic at the Universitat de València, using brand-new generated educational videos as learning material to be supplied in advance to students. The originality of the proposed methodology lies in the transformation of the passive attitude of the students towards active and participative teaching, so that the students can solve problems in the classroom making a joint venture and facilitating them the formulation of doubts and difficulties. Among the advantages that we can find in this methodology we emphasize the fostering of self-learning and active learning in the students, as they are encouraged to learn the video contents at home, and then they put in practice this new knowledge in classroom. In this way, the student has more chances to learn and allows her/him to go beyond the simple acquisition of knowledge.

\section{ACKNOWLEDGEMENTS}

This work has been developed within the research project "Aprenentatge autònom $i$ cooperatiu, $i$ assimilació de continguts mitjançant I'ús de vídeos docents" (Ref.: UV-SFPIE_RMD18-842105) funded by the "Vicerectorat d'Ocupació i Programes Formatius" de la Universitat de València.

\section{REFERENCES}

[1] A. García-Barrera, "El aula inversa: cambiando la respuesta a las necesidades de los estudiantes", in Avances en Supervisión Educativa, 2013.

[2] G. L. Huber. "Aprendizaje activo y metodologías educativas". Revista de Educación, no. 2008, pp. 59-81, 2008.

[3] A. García Crespo, R. Colomo Palacios, J.M. and G. Berbís. "La asignatura Expresión oral y escrita dentro del Grado en Ingeniería Informática adaptado al Espacio Europeo de Educación Superior". IEEE-RITA, vol. 4, no. 2, 2009.

[4] P. Fernández Sánchez, A. Salaverria Camacho, J. González Dacosta and E. Mandado Pérez. "EI aprendizaje activo mediante la autoevaluación utilizando un laboratorio virtual". IEEE-RITA, vol. 4, no. 1, 2009. 